\title{
Children's pensions: How to develop an accessible and understandable personal savings habit that produces an adequate retirement income
}

Received (in revised form): 12th September, 2007

\section{Niall Doyle}

is the Corporate Affairs Manager for the Irish Insurance Federation. He has made several submissions to government on pensions policy including children's pensions. His most recent is a soft-mandatory system, sharing costs between the social partners and giving limited pre-retirement access to funds, covering 69 per cent of the labour force and providing significantly higher benefits than the current system. Concurrently he proposes increasing the retirement age and providing a universal state pension based on age and residency status alone. He is on the National Steering Group for Financial Literacy and advocates realistic mathematics education in second-level education.

\begin{abstract}
While acknowledging that there is an important but tiny number of far-sighted, visionary, actuarial adolescents who have the capacity and inclination to plan for their retirement 47 years hence, the rest of us need a little help. This help should take the form of a kick-start from Uncle Gordon, support and encouragement from Mum and Dad, understanding/education, self-help in the form of personal contributions, and a reward within a realistic timeframe. The solution is simple: children's pensions. Alternatively, continue wasting time telling 18 year olds that they should start saving for their pension which will be really useful when they are 65 , less tax.
\end{abstract}

Pensions (2007) 12, 213-216. doi:10.1057/palgrave.pm.5950057

Keywords: children's pensions, savings gap, access to funds, soft-mandatory, savings habit, dependency ratio

Try at the outset of this article to forget all you ever knew about pensions. I've been with the Irish Insurance Federation for three years. When I started working here, I had no previous experience in the industry and no private pension provision. A little over two years ago, I was asked to take a look at the Irish Savings Gap to see whether our industry should be making specific or general policy recommendations to Government with the aim of closing it.

To understand something about the Pensions Gap (I didn't know anything), I took the advice of a financial advisor and logged into the ABI's pension calculator; the IIF didn't have one at the time. I entered my current age (38 at the time),

Correspondence: Niall Doyle, Irish Insurance Federation, Insurance House, 39 Molesworth Street, Dublin 2, Republic of Ireland.

Tel: +35316447787; Fax: +35316761943; E-mail: niall.doyle@iif.ie when I wanted to retire, the contributions I was willing to make and pressed 'go' - The shock I received was substantial! I started to manipulate the figures by putting in more money and working for longer. The pension started to improve, but not significantly, not unless I put in about 30 per cent of my earnings, and worked well past when I had hoped to retire.

I was beginning to understand the problem!

What if I had started at 18 ? Things started to look much brighter. Then I had a flash back to what I used to think about when I was 18. Suffice to say it did not involve long-term financial planning. In fact, retirement has only come into my perspective following the birth of my first child. At the risk of generalising from my personal specific, I cannot believe that my own experience at 18 - and for the following ten years at least - differs largely from that of the 
majority of the population. (My apologies to those far-sighted, visionary, actuarial adolescents who have the capacity and inclination to plan for their retirement 47 years hence!)

At least I now understood that an adequate pension comes from saving enough for long enough. The solution I concluded was to somehow reconcile an adolescent's view of the world with the necessity to begin saving for retirement when still a teenager. Impossible!

Then my 2-year-old, Sarah, woke up from her nap and the solution came to me.

- A personal pension account is opened for every child in the country and the Government deposits $€ 10$ a month into each account until she (Sarah, for example) turns 18.

- Meanwhile, Sarah is taught about financial planning, including pensions, in her secondlevel school. (This proposal has already been made to Government and has received widespread public support. Why should Sarah be allowed to leave school without understanding the basic living skill of budgeting income versus expenditure?)

- Sponsor(s) (parent, guardian, godparent, grandparent, etc) may make additional contributions from NET earnings to Sarah's account of up to $€ 50$ per month in total over the same time period (ie until her 18th birthday).

- For every $€ 5$ contributed by sponsors, the Government contributes an additional $€ 1$. (This element mirrors the successful 'onefor-four' aspect of the SSIA ${ }^{1}$ scheme, which provides irrefutable evidence that the population understands/appreciates/ values a tax-credit Government top-up scheme over a tax-relief scheme despite the long-term financial superiority of taxrelief.)

- Responsibility for making contributions to the fund falls to Sarah at age 18 (Table 1).

- On Sarah's 25th birthday, she gets access to 25 per cent of the current value of the fund tax-free if and only if she has been contributing at least 5 per cent of earnings when working.

- On her 35th birthday, she gets access to a further 20 per cent of the current value of the fund tax-free, provided she has been contributing at least 10 per cent of earnings between the ages of 25 and $35 .^{3}$

- The remainder cannot be accessed until retirement, unlike the child trust fund in the UK, which gives all the money back (Table 2).

\section{Final fund values}

Assume that 25 per cent of the fund is taken at age 25 , a further 20 per cent of the fund is taken at age 35 and contributions are continued at 15 per cent thereafter until retirement at 65 ; then, even scenario 1 in Table 2 below provides over 22 per cent of the final salary income on retirement. Add that to one's guaranteed State Old Age Contributory Pension of 34 per cent of the Average Industrial Wage and even those on lower incomes can expect a substantial improvement in their retirement living standards. ${ }^{4}$

\section{Benefits}

- Sarah, along with every child in the country, automatically has a growing private pension fund from birth, which she can't opt out of and about which she receives regular personalised benefit statements;

Table 1: Costs

\begin{tabular}{lccc}
\hline & Number of children & Monthly contribution & Annual contribution \\
\hline Government contribution & $1,076,040$ & $€ 10$ & $€ 130 \mathrm{~m}^{2}$ \\
Cost to sponsors & & $€ 0-50$ & $€ 0-600$ \\
& & \\
Assume children sponsored for $€ 20$ per month or $€ 240$ pa then additional cost to Government: & $€ 26 \mathrm{~m}$ \\
Government credit & $50 \%$ of children & $€ 2.15 \mathrm{~m}$ & $€ 52 \mathrm{~m}$ \\
Government credit & $100 \%$ of children & $€ 4.3 \mathrm{~m}$ & \\
\hline
\end{tabular}

Note: Total costs to government based on these assumptions are approximately one-third of the annual SSIA government spend. 
Table 2: Fund values

\begin{tabular}{|c|c|c|c|}
\hline & Age 18 & Age 25 & Age 35 \\
\hline \multicolumn{4}{|l|}{ SCENARIO 1} \\
\hline $\begin{array}{l}\text { Basic plan with no contributions above Government } € 10 \text { per month up to age } 18 \text {. } \\
\text { Individual then contributes } 5 \% \text { of earnings from age } 18 \text { and } 10 \% \text { from age } 25 \text {. }\end{array}$ & $€ 3,467$ & $€ 14,374$ & $€ 60,001$ \\
\hline \multicolumn{4}{|l|}{ SCENARIO 2} \\
\hline $\begin{array}{l}\text { Sponsor matches Government contribution of } € 10 \text { per month upto age } 18 \text {. } \\
\text { Individual then contributes } 5 \% \text { of earnings from age } 18 \text { and } 10 \% \text { from age } 25 \text {. }\end{array}$ & $€ 7,627$ & $€ 20,228$ & $€ 67,152$ \\
\hline \multicolumn{4}{|l|}{ SCENARIO 3} \\
\hline $\begin{array}{l}\text { Sponsor matches Government contribution of } € 10 \mathrm{pm} \text { upto age } 18 \text {. Individual then } \\
\text { contributes } 5 \% \text { of earnings from age } 21 \text { and } 10 \% \text { from age } 25\end{array}$ & $€ 7,627$ & $€ 16,119$ & $€ 62,133$ \\
\hline \multicolumn{4}{|l|}{ SCENARIO 4} \\
\hline $\begin{array}{l}\text { Sponsor doubles Government contribution of } € 10 \text { per month upto age } 18 \text {. } \\
\text { Individual then contributes } 5 \% \text { of earnings from age } 18 \text { and } 10 \% \text { from age } 25 \text {. }\end{array}$ & $€ 11,787$ & $€ 26,081$ & $€ 74,303$ \\
\hline
\end{tabular}

Assumptions: 6 per cent growth less 1 per cent charges; Starting Salary=S20,000 or £13,666 Sterling; Assume inflation (wage and contribution) of $4.5 \%$; Assume 25 per cent of the fund taken at age 25

- At 18 she may cease contributions but with schools, parents, Government and industry all promoting the funding of these products, private pension provision will become the norm;

- Access to a portion of the fund at crucial times in Sarah's life cycle provides a significant incentive to contribute that helps foster a positive attitude to saving and a savings habit;

- Making the future secure for their children allows parents to spend more time and resources making the future more secure for themselves;

- The volume of accounts - 100 per cent of the population over time - and the simplicity of the product will generate increased competition in the industry, which in turn will promote competitive charging and value-adding customer services;

- Sarah and her cohorts will take more financial responsibility for their own retirement;

- State expenditure reduces - over time

- because well-financed pensioners:

- Pay tax;

- Have private health insurance; and

- Spend money in the economy.

- This proposal reduces Irish society's dependency on the pay-as-you-go system thus de-politicising pension provision; and

- It could pave the way for the incremental introduction of soft mandatory (opt out) pensions for this new work force, including all public servants.

\section{Some criticisms and answers}

- The fund values at 18 or 25 will be an insignificant addition to the pension at 65 . To discuss it in those terms is to completely miss the point. This proposal is not initially about the size of the fund; it is about the development of a 'Savings Habit' at an early age, which, if successful, becomes a habit of a lifetime and consequently produces an adequate retirement income.

- What does 'Pensions for Children' do for the current workforce?

- Remember 70,000 of these children join the 'current' workforce every year;

- We cannot expect to develop a macro solution to the pension crisis without including those not yet in the workforce especially as PAYGO assumes that our children will pay for our increased longevity and bear the consequences of a reduced dependency ratio. We cannot continue to pass an ever-worsening problem on to our children;

- Critically, it allows the parents of these children - the current workforce (if they see their children being well 
provided for) the facility to consider and fund their own retirement. Parents will learn from the experience of their children. This in turn will reinforce the positive and necessary aspects of saving to both groups;

\section{- Some parents will afford maximum contributions} while others will only afford minimum or none at all. Similar to the SSIA scheme, not everyone can afford maximum contributions, but does that mean you should abandon a scheme that gives 100 per cent coverage and develops a national savings culture because some 'rich kid' doesn't need it? The significant value is built up during the 18-25-year period, that is, when the child alone contributes to the fund.

\section{Conclusion}

To develop a personal savings habit, you need an individual product with your name on it, a kickstart from the Government, support and encouragement from Mum and Dad, understanding/education, personal contributions and a reward within a realistic timeframe. All this must be contained within a simple product that is understandable to the overwhelming majority. Of course, the alternative is to say to Sarah as she turns 18 that she really should open up a pension account that she can get at in 47 years, less tax!

\section{Notes}

1 SSIAs, Special Savings Incentive Accounts, a remarkably successful Government initiative designed 'officially' to encourage the population to think positively about saving and perhaps take some of the heat out of the Irish economy. Over five years, for every S4 an individual puts into his/her account up to a maximum of $€ 254$ per month the Government puts in an additional $€ 1$. Over 25 per cent of all citizens contribute to an account. When the five years are up, access is given to the whole fund less a 23 per cent tax liability on the Capital Gain. This maturation occurs during the 12 months preceding the next general election!.

$2 € 130 \mathrm{~m}$ is approximately 10 per cent of the Government's annual contribution to the National Pension Reserve Fund.

3 If the Government feels that it needs compensation for this taxfree early access and/or there are concerns that this access will dilute the final values, then consider reducing or eliminating the tax-free lump sum an individual is entitled to on retirement. Remember ... 'A bird in the hand...'.

4 Mandatory and opt-out systems, the privatisation of PAYGO and eliminating the distinction between contributory and noncontributory, that is, eliminating means testing, are inextricably linked but these are topics for another paper. 